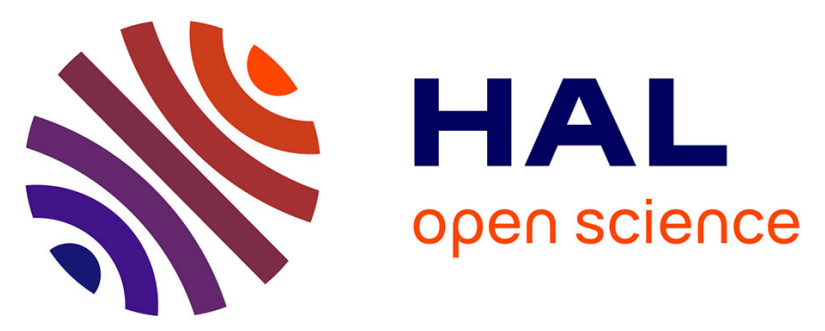

\title{
A weight-of-evidence approach to assessing the ecological impact of organotin pollution in Dutch marine and brackish waters; combining risk prognosis and field monitoring using common periwinkles ()
}

Cor A. Schipper, Mathijs G.D. Smit, Nicholas H.B.M. Kaag, A. Dick Vethaak

\section{To cite this version:}

Cor A. Schipper, Mathijs G.D. Smit, Nicholas H.B.M. Kaag, A. Dick Vethaak. A weight-of-evidence approach to assessing the ecological impact of organotin pollution in Dutch marine and brackish waters; combining risk prognosis and field monitoring using common periwinkles (). Marine Environmental Research, 2008, 66 (2), pp.231. 10.1016/j.marenvres.2008.02.070 . hal-00501962

\section{HAL Id: hal-00501962 https://hal.science/hal-00501962}

Submitted on 13 Jul 2010

HAL is a multi-disciplinary open access archive for the deposit and dissemination of scientific research documents, whether they are published or not. The documents may come from teaching and research institutions in France or abroad, or from public or private research centers.
L'archive ouverte pluridisciplinaire HAL, est destinée au dépôt et à la diffusion de documents scientifiques de niveau recherche, publiés ou non, émanant des établissements d'enseignement et de recherche français ou étrangers, des laboratoires publics ou privés. 


\section{Accepted Manuscript}

A weight-of-evidence approach to assessing the ecological impact of organotin pollution in Dutch marine and brackish waters; combining risk prognosis and field monitoring using common periwinkles (Littorina littorea)

Cor A. Schipper, Mathijs G.D. Smit, Nicholas H.B.M. Kaag, A. Dick Vethaak

PII:

S0141-1136(08)00096-2

DOI:

10.1016/j.marenvres.2008.02.070

Reference:

MERE 3242

To appear in:

Marine Environmental Research

Received Date:

1 October 2007

Revised Date:

18 February 2008

Accepted Date:

19 February 2008

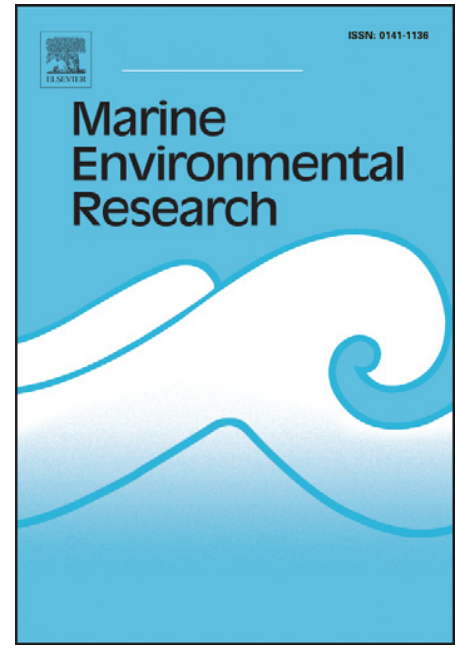

Please cite this article as: Schipper, C.A., Smit, M.G.D., Kaag, N.H.B., Vethaak, A.D., A weight-of-evidence approach to assessing the ecological impact of organotin pollution in Dutch marine and brackish waters; combining risk prognosis and field monitoring using common periwinkles (Littorina littorea), Marine Environmental Research (2008), doi: 10.1016/j.marenvres.2008.02.070

This is a PDF file of an unedited manuscript that has been accepted for publication. As a service to our customers we are providing this early version of the manuscript. The manuscript will undergo copyediting, typesetting, and review of the resulting proof before it is published in its final form. Please note that during the production process errors may be discovered which could affect the content, and all legal disclaimers that apply to the journal pertain. 


\section{ACCEPTED MANUSCRIPT}

1 12 February 2008

2 A weight-of-evidence approach to assessing the ecological impact of organotin pollution in Dutch

3 marine and brackish waters; combining risk prognosis and field monitoring using common

4 periwinkles (Littorina littorea)

5

6 Cor A. Schipper ${ }^{\dagger}$, Mathijs G.D. Smit ${ }^{\ddagger}$, Nicholas H.B.M. Kaag ${ }^{\ddagger}$ and A. Dick Vethaak ${ }^{\dagger}$.

7 † Deltares, P.O. Box 69, 2600 AB Delft, the Netherlands

$8 \neq$ TNO IMARES, Inst. of Marine Resources and Ecosystem Studies, P.O. Box 57, 1780 AB Den Helder, 9 the Netherlands.

10
Corresponding author;

\section{C.A. Schipper}

Postal address: P.O. Box 177, 2600 MH Delft, The Netherlands

Telephone $+31 .(0) 15.2858684$

Fax: ++31 - 015-2858582

E-mail address: cor.schipper@deltares.nl

Keywords: Gastropods, harbours, tributyltin, intersex, risk assessment, sediments, SPM. 
1 Abstract

2

In the present study an integrated ecological risk assessment based on multiple lines of evidence (LOEs) was evaluated in order to better assess the risk from TBT in Dutch harbours and open coastal waters. On the basis of spatial distributions of measured tributyltin (TBT) concentrations in sediments and suspended matter, predictions of the intersex index (ISI) in Littorina littorea and the ecological risk expressed as the Potentially Affected Fraction (PAF) of species were made. The results were compared to actual ISI measurements and presence of $L$. littorea in the field. The PAF calculated on the basis of TBT levels for open coastal waters ranged from $4.2 \%$ to $15.3 \%$; for harbours it ranged from $3.5 \%$ to $26.9 \%$. Significant intersex levels were observed only in waters where the risk was calculated above 10\% PAF. This study suggests that the absence of $L$. littorea from some harbours with high ecological risk values can be explained by high TBT concentrations. A call is made for the use of integrated approaches like weight of evidence (WOE) to help practitioners improve ecological risk assessment.

\section{Introduction}

Tributyltin (TBT) was first used as an antifouling agent in the late 1960s. It proved to be very effective, but also extremely toxic to aquatic life (Champ and Seligman, 1996). TBT effects were first recognized in the marine environment in the 1970s and attracted particular attention in the 1980s, when the effects of TBT started to become apparent in the Netherlands and elsewhere (Marquenie and Vethaak, 1989; Champ and Seligman, 1996). In the 1980s, there was a sharp decline in the population of dog whelk (Nucella lapillus) in the Delta area of the south-western Netherlands and in the 1990s the occurrence of imposex was demonstrated among whelks (Buccinum undatum) in the same area (Mensink et al., 1996) as well as in the open North Sea (Ten Hallers-Tjabbes et al., 1994). 
1 Given the concern about the environmental effects of TBT in the Dutch marine environment a lot of data

2 has been collected in the past. The available data relate to TBT concentrations in water, sediments and

3 suspended matter and field measurements of intersex in, and the distribution and abundance of

4

5 gastropods. The Chemical Toxicity Test (CTT) has shown TBT to be the most problematic of all the chemicals tested in toxicological terms in assessing whether dredged material may be relocated in the marine environment (Schipper and Schout, 2004). Up to now, in assessing the impact of TBT on the ecosystem, the available information has been evaluated separately. This paper describes the results of an integrated assessment including all the information collected in recent years. Comparable to the sediment quality Triad concept, which uses information from the toxicity line, the biological field line and the chemistry line, this assessment is also based on results of three lines of evidence (LOEs) (Chapman, 1996; Rutgers, 2000). However, instead of using measurements from multiple species in the biological field line, as normally done in the Triad approach, the assessment in the present study uses information from one indicator species only. In the present study the LOEs are primarily represented by measurements of: (i) chemical concentrations (exposure levels), (ii) (eco)toxicological indicators and results from ecotoxicological laboratory experiments, and (iii) abundance of indicator species Littorina littorea in the field. The Potentially Affected Fraction of species (PAF) was used to represent the ecological risk and quantify the degree of TBT stress on the ecosystem (Aldenberg et al., 2002). All three LOEs provide indications of the ecological health status related to TBT pollution, though all approaches based on this level include uncertainties:

i. TBT pollution is directly chemically measured in samples collected in the field. However, the relevance of chemical analysis of sediments to the quality of water bodies is not always clear. Processes such as bioavailability determine the actual relation between chemical concentrations and possible ecological effects. Ecological risk prognosis, using accepted generic procedures, predicts the health status related to the stressor under consideration based on the measured or estimated chemical concentrations assuming equilibrium partitioning and constant bioavailability. The prognosis will provide the likelihood of effects to occur. Whether or not these effects will actually occur depends on location specific conditions.

ii. Biological effect parameters can be used to assess the potential and actual impacts of TBT on marine coastal life. However, it can be difficult to link biological effects to exposure to a single contaminant. In this study, the degree of intersex index (ISI) in the common periwinkle, L. littorea, was selected as an indicator of TBT pollution, as this species is the most common prosobranch species on hard substrates in Dutch coastal waters. Intersex in this species has proven to be sensitive to the degree of environmental organotin pollution in coastal waters (Oehlmann et al., 1998). Although periwinkles are not the most sensitive gastropod and ISI is not a rapid response, 
measuring ISI levels in L. littorea in the field is still a useful way of assessing effective levels of TBT pollution. Several studies have shown that ISI can be used as biological tool to determine the degree of TBT pollution, which can be expressed as approximate TBT concentrations in seawater (Stroben et al., 1992; Oehlmann et al., 1998). However, the ISI indicator in periwinkles cannot easily be translated to a generic health indicator for the water body under consideration.

iii. Observations from biological effect monitoring at gastropod level (Ten Hallers-Tjabbes et al., 1994; Mensink, 1996; De Wolf, 2001) are used to assess effects of the distribution and contamination levels in the Dutch marine environment. The abundance of $L$. littorea and the far more sensitive dog whelk, $N$. lapillus, can be used as indicators. TBT contamination has made the dog whelk a rare species in Dutch coastal waters and it is almost entirely absent from harbours and marinas (Harding et al., 1992; Van Moorsel, 1996). TBT potentially accumulates in sediments. However, there is no direct link between sediment concentrations and effects in gastropods, as the preferred habitats of some of the most common gastropods (e.g. N. lapillus, L. littorea) are hard substrates, including natural substrates such as rock and artificial substrates such as harbour walls, breakwaters, etc. (Oehlmann, 2002).

In this study the results of the LOEs are compared in order to establish their similarity and reduce the uncertainty of the overall assessment. The methodological links between different LOEs must be evaluated so that the results of monitoring effects on L. littorea and risk assessment studies focusing on the impacts of TBT can be compared. This paper describes a WOE approach (Smith et al., 2002) focusing on TBT in Dutch harbours and open waters. Focusing on the integration of indicator monitoring and risk prognosis, the present study applies a more holistic approach to impact assessment (Suter II, 2001).

\section{Materials and Methods}

\subsection{Study area}

An integrated ecological risk assessment approach including evaluation of three LOEs is applied to the collected data to assess ecological health status related to TBT pollution in Dutch marine and estuarine 
1 waters. Figure 1 shows the harbour locations 1 to 30 and the seven open water areas (A to $G$ ) from

2 which chemical, (eco)toxicological and/or ecological data have been included in this study.

3

4

5

6

\subsection{Chemistry}

The top $5 \mathrm{~cm}$ of sediment was sampled using a box core at 120 locations along the Dutch coast between 1998 and 2003. Over this period, 106 locations were sampled twice with an interval of three years. The locations covered the main open North Sea waters, the Wadden Sea, the Eastern Scheldt and estuarine areas such as the Western Scheldt and Ems-Dollard (see Figure 1). TBT was also analysed in sediment from a number of harbour locations from 1999 to 2002 (Table 1).

TBT in suspended particulate matter (SPM) was measured four times a year at eight locations in four different open water areas ( A. Ems-Dollard; B. Wadden Sea; C. North Sea; E. Eastern Scheldt; G. Western Scheldt, Figure 1) along the Dutch coast between 1998 and 2003, giving information on fluctuations between and within years. A further 17 locations (data not shown) from the French-Belgian border to the Ems-Dollard estuary on the Dutch-German border were sampled in 2003. Suspended matter was sampled by pumping surface water through a flow-through centrifuge lined with Teflon plates to collect the suspended matter. At harbour locations 23 and 29 (see Figure 1) the seasonal variation of water-dissolved TBT was sampled from 1999 to 2002.

The sediments were freeze-dried and homogenized using a Retsch planetary ball mill. $1.5 \mathrm{ml}$ acetic acid, $15 \mathrm{ml}$ methanol and $7 \mathrm{ml}$ hexane were added to $1 \mathrm{~g}$ of sediment. This mixture was stirred for $30 \mathrm{~min}$, after which $3 \mathrm{ml}$ of $4 \mathrm{M}$ sodium acetate solution $(\mathrm{pH}=5)$ was added to obtain optimal ethylation. Then, $4 \mathrm{ml}$ of $5 \%$ sodium tetraethyl borate solution was slowly added using a peristaltic pump over 20 min, during which time the mixture was continuously stirred. The mixture was shaken vigorously and $5 \mathrm{ml} 10 \mathrm{M}$ sodium hydroxide solution added to remove boroxin formed at ethylation. About $5 \mathrm{ml}$ of water was added, and after shaking and subsequent centrifugation the hexane layer with the ethylated organotin compounds was collected. This hexane extract was cleaned over a column of 4-gramme aluminium oxide (Alumina B-super deactivated with 10\% water) using hexane as an eluent. $1 \mathrm{ml}$ of iso-octane was added to the hexane eluate and this extract was then concentrated to a final volume of $0.5 \mathrm{ml}$ using KudernaDanish solvent evaporation. The final extracts were analyzed for ethylated organotin compounds by 
1 electron impact (EI) GC-MS using selective ion monitoring. The method uses ethylated Quasimeme standards and tetrapropyltin as internal standard. Quality assurance recovery control with carried out with monopropyltin and tripropyltin in each sample and blank control in every analysis batch. Yearly participation in Quasimeme laboratory proficiency exercises for organotins resulting in satisfactory zscores.

\subsection{Probabilistic risk assessment methods}

The measured TBT-Sn concentrations were used as a basis for a probabilistic risk assessment. In those samples where the fraction organic carbon $\left(f_{o c}\right)$ was reported, the sediment and suspended matter concentrations from the field surveys were normalised to water concentrations, applying the formulas in the European Technical Guidance Document for Risk Assessment (EC, 2003). The ecological risk expressed as the Potentially Affected Fraction of species (PAF) was calculated in accordance with Aldenberg et al. (2002). This method can be summarised as follows. The calculated water concentrations were compiled in a log-normal distribution representing the spatial variation of TBT concentrations in a specific area. The concentration distribution was then compared to the species sensitivity distribution (SSD) for TBT. The SSD describes the average sensitivity of species and the variation among species (Posthuma et al., 2002). The SSD for TBT reported by Lepper (2002) is based on toxicity data for 29 marine and freshwater species representing seven taxonomic groups (algae, annelida, crustacea, echinodermata, insecta, mollusca, pisces). The SSD for TBT-Sn used in this study is provided in the supplementary data for this paper.

The PAF indicates the likelihood that adverse ecological effects will occur as a result of TBT exposure in a particular area. This value can be interpreted as the probability that a randomly selected exposure concentration will exceed species sensitivity. The probabilistic risk assessment was performed on the clustered data for harbours and for open waters, as well as for each harbour and open water separately. Only water systems for which exposure concentrations were measured at two or more locations were selected (all open waters and 19 out of 30 harbours). 
1 The likely range of the intersex indicator (ISI) for $L$. littorea was also calculated based on the dose-

2 response relationship for $L$. littorea as published by OehImann (2002) and the spatial distribution of water

$$
I S I=\frac{3.35}{1+\exp \left(\frac{-\left(P E C_{\text {seawater }}-18.3\right)}{4.73}\right)}
$$

7 concentration distributions were calculated applying Formula 1.

(1)

where:

$I S I=$ calculated ISI level [-]

$P E C_{\text {seawater }}=$ concentration of TBT-Sn in seawater $\left[\right.$ ng. $\left.I^{-1}\right]$

\subsection{Biological effects and abundance surveys}

\subsection{Overview of chemical and biological datasets} within the areas.

\section{Results}

\subsection{Observed and predicted exposure levels} concentrations. The range of possible ISI values from the $5^{\text {th }}$ and $95^{\text {th }}$ percentile of the exposure

Periwinkles were sampled from 2002 to 2005 at 42 locations along the Dutch coast, representing the main Dutch open waters areas and harbour locations (Figure 1). Grevelingen (D) and Veersemeer (F) lakes were not included. At the sampling locations the presence of $L$. littorea was recorded at every location randomly selected in 5 to 7 areas of $1 \mathrm{~m}^{2}$. If present, at least 40 individuals of $L$. littorea with a shell height between 15 and $25 \mathrm{~mm}$ (approx. 1.5-year-old new adults) were collected. The occurrence of intersex in the periwinkles was analysed within seven days, in accordance with the methods described by Bauer et al. (1995). ISI is expressed as the average intersex stage within the population.

Table 1 lists the chemical and biological datasets compiled for this study. The number of 'areas' refers to the open waters presented in Figure 1. The number of 'locations' refers to different sampled harbours 
1 The observed concentration ranges of TBT in sediment or SPM in Dutch open waters and 19 Dutch

2 harbours are shown in Table 2. The highest observed TBT-Sn concentration in Dutch harbours was a

3 factor 30 higher than the highest TBT-Sn concentrations in open waters. The lowest TBT concentrations

4 were more or less in the same range. In order to normalise the sediment and suspended matter

5 concentrations to water concentrations a value for the $\mathrm{K}_{\mathrm{oc}}$ (organic carbon partition coefficient) needs to

6 be estimated. From the distribution of measured sediment and water concentrations in Dutch harbours a

7 value for the $K_{o c}$ representative of the Dutch situation was estimated. A value of 5.34 gave the best

8 correspondence between observed and predicted water concentrations in Dutch waters (More

9 information on how this value was obtained can be found in the supplementary data). As no temporal

10 trends were observed in the concentrations of TBT-Sn in either the open waters or the harbours, the average concentration of TBT-Sn was taken to represent the exposure at a sampling location. This average concentration was used for further analysis in the risk predictions. Since the concentration distributions of the normalised sediment samples and SPM samples did not differ significantly (Student's t test, equal variances, $p=0.42$ ), the normalised data of the two distributions were pooled. Figure 2 presents the overall exposure concentration distributions for TBT-Sn for 138 open water and 270 harbour locations respectively.

Dedicated exposure concentration distributions were derived for all areas and locations (open waters and harbours), representing the spatial distribution of water concentrations for each area. In Table 2 the $5^{\text {th }}$ and $95^{\text {th }}$ percentile of the distribution represent the range of water concentrations for each area.

\subsection{Predicted ecological risk}

The two distributions presented in Figure 2 were used as input for a probabilistic risk assessment as described by Aldenberg et al. (2002). This resulted in an expected total ecological risk for open waters of $6.7 \%$ and $19.1 \%$ for harbours. This implies that, on average, for open waters it is likely that $6.7 \%$ of species will be negatively affected as a result of exposure to TBT. For the harbours this fraction is $19.1 \%$. The risk values for the individual open waters and harbours are given in Table 2. Relatively high-risk values were obtained for open waters in the Western Scheldt (G) and Veersemeer (F), while the risk values for the Wadden Sea (B) and the Eastern Scheldt (E) were below 5\%. For harbours the highest risk 
1 value was predicted at Harlingen in the Wadden Sea (location 8). Four harbours, all small harbours in the

2 Wadden Sea, yielded a risk value equal to or lower than the lowest risk value for the individual open water bodies (see Table 2). The table presents the observed and predicted concentrations and ISI levels in L. littorea. The ecotoxicological risk presented as PAF can be interpreted as the characterization of the potential adverse health effects of exposure to environmental hazards. The $5^{\text {th }}$ and $95^{\text {th }}$ percentiles of the exposure concentration distribution in the dedicated open water or harbour were used to calculate the range of ISI values likely to occur in the area. The upper and lower limits of the calculated ISI values are reported in Table 2.

\subsection{Observed ISI values and species abundance}

ISI observations are available for the open waters, except for Grevelingen (D) and Veersemeer (F) lakes, where no ISI sampling was carried out. The observed ISI values for open waters were relatively low. The highest ISI value was observed in the Western Scheldt. Ten harbours were selected for ISI sampling. However, since no periwinkles were found in Harlingen (location 8), ISI observations are available for only 9 harbours. Periwinkles with low abundance were found at the harbours in Delfzijl (location 1), Den Helder (location 14), IJmuiden (location 15) and Rijnmond (location 18). Much higher ISI levels were observed in harbours than in open waters. The highest value (3.0) was observed in Den Helder (location 14). The wide range of ISI levels observed in Vlissingen harbour (location 25) indicates that a high variation in ISI levels can exist within a single harbour.

\subsection{Comparison of the LOE results}

To check the correspondence between the maximum ISI levels that can be expected in a harbour and the ecological risk, PAF values have been plotted against the calculated ISI value corresponding to the $95^{\text {th }}$ percentile of the exposure concentration distribution (Figure 3). The $95^{\text {th }}$ percentile was chosen because this value corresponds to the most polluted part of the harbour or water body corresponding to a maximum ISI value that might be encountered during field monitoring. In ecological risk prognosis a Potentially Affected Fraction of $5 \%$ of species is generally considered acceptable (e.g. Van Straalen and Denneman, 1989; Aldenberg and Slob, 1993; Newman et al., 2000; Van der Hoeven, 2001; EC, 2003). This study shows that at this $5 \%$ level intersex in L. littorea is unlikely to occur in the field. But even at 


\section{ACCEPTED MANUSCRIPT}

1 higher risk levels, up to approximately $10 \%$, ISI levels in the field are not expected to exceed the ISI

2 signalling level of 0.3 (Oehlmann, 2002). This study showed that high ISI levels up to a maximum of 3.35 are expected in the field only when the predicted risk level exceeds $20 \%$. These results indicate that either the ISI measurements in L. littorea are not sensitive enough to assess ecosystem health, or the risk prognosis is too conservative (predicting risks while there are no actual effects).

In order to check whether the conservatism in the risk assessment is a result of the estimated concentrations (chemistry LOE), the calculated ranges of ISI values based on the $5^{\text {th }}$ and $95^{\text {th }}$ percentile of TBT concentrations are compared by the observed ISI values in the field (Ecotoxicity LOE). If there is a good correspondence between calculated and observed ISI, it can be concluded that the concentrations are a proper basis for the risk calculations as well. Figure 4 presents the comparison between calculated and observed ISI for open waters (A) and Dutch harbours (B).

The observed ISI values were relatively low for open waters, often below the $5^{\text {th }}$ percentile of the predicted ISI range based on the TBT concentrations. Given the TBT concentrations in the Western Scheldt (G) and Veersemeer (F), predicted ISI values around 1.0 might be expected. Although intersex was observed at a low level $(I S I=0.15)$ at one location in the Western Scheldt, the observations never exceeded the signalling level of 0.3 (Oehlmann, 2002). Nearly all observed ISI levels in harbours fall within the ISI ranges corresponding to the median and $95^{\text {th }}$ percentile of the exposure concentrations. The ISI levels observed in IJmuiden (location 15), Den Helder (location 14), Vlissingen (location 25) and Lauwersoog (location 3) corresponded to the upper $25 \%$ of the exposure concentrations. At 4 other harbours - Delfzijl (location 1), Yerseke (location 22), Scheveningen (location 17) and Rijnmond (location 18) - the observed ISI levels corresponded to the upper $50 \%$ of the exposure concentrations. Maximum intersex levels are predicted for three harbours (locations 8, 14 and 18) where no periwinkles were found at some stations. In IJmuiden (location 15) and Delfzijl (location 1), where periwinkles were in low abundance, the maximum calculated ISI level is around 1.5.

\section{Discussion}


1 In the present study a weight-of-evidence approach derived on the basis of three LOEs has been

2 evaluated in order to better assess the risk from TBT in Dutch harbours and open waters. Based on chemical data, risk values were determined according to Aldenberg et al. (2002) and ISI values were calculated based on the dose-response curve reported by Oehlmann (2002). Actual ISI observations were made in the field and the presence of gastropods was recorded. In the overall approach evidence from the different LOEs was combined.

The partition coefficient $\left(\mathrm{K}_{\mathrm{p}}\right)$ was used for the conversion of TBT concentrations in sediment and SPM to TBT concentrations in water. This $\mathrm{K}_{\mathrm{P}}$ for TBT was calculated by multiplying the organic carbon partition coefficient $\left(\mathrm{K}_{\mathrm{oc}}\right)$ with the measured fraction organic carbon $\left(\mathrm{f}_{\mathrm{oc}}\right)$. Consequently, the $\mathrm{K}_{\mathrm{oc}}$ value has a strong impact on the final results of the risk prognosis. Generally, in risk predictions the lowest $\mathrm{K}_{\mathrm{oc}}$ value is applied to calculate concentrations in water (EC, 2003). This results in a worst-case water concentration, in accordance with the precautionary principle. However, with literature values for the $\mathrm{K}_{\mathrm{oc}}$ of TBT ranging from $3.0-6.2$ (Lepper, 2002), it is more appropriate to base an assessment on local measured values. In this study the $\mathrm{K}_{\mathrm{oc}}$ value was estimated from measured aqueous and sediment concentrations in 30 Dutch harbours evenly distributed over the Netherlands. This resulted in an average $\mathrm{K}_{\mathrm{oc}}$ value of 5.34 (see also the supplementary data). This outcome is within the range of reported $\mathrm{K}_{\mathrm{oc}}$ values from the literature (Lepper, 2002).

The highest ISI value, measured in the Western Scheldt (G), still fell within the predicted ISI range. Higher ISI values for samples from the Western Scheldt $(G)$ have, however, been reported by De Wolf et al. (2001 and 2004), showing a decline from 1.3 in 1998 and 2001 to 0.5 in 2002. This decline was confirmed by the surveys reported here, where an ISI of 0.15 was found at the same location in 2002 , using only young adults. This is comparable to the ISI value reported by De Wolf et al. (2004), as these were adults that had been exposed some years before the young adults were exposed. In contrast to the trend in the ISI, no downward trend in the sediment-derived water concentrations from 1998 to 2003 was observed in the Western Scheldt (G). We can conclude from the data that observed ISI levels in open waters are all in the lower range of predicted ISI levels. 
1 The results of the risk predictions confirm that $L$. littorea is not the most sensitive species regarding to

2 TBT pollution (Oehlmann et al., 1998; Ospar, 2003). In the field, significant effects on intersex levels are expected for this species only when the risk level exceeds $10 \%$, whereas a risk level of $5 \%$ is generally considered acceptable for the protection of ecosystem health (e.g. Van Straalen and Denneman, 1989). High ISI levels, up to a maximum of 3.35 , are expected only when the risk level exceeds $20 \%$. At these high ISI levels, up to a maximum of 3.35, the population of $L$. littorea is expected to be completely sterile (Oehlmann, 2002). It may even be argued that a risk level of $5 \%$ is far too high for specifically acting toxicants such as TBT. Even though $L$. littorea is not the most sensitive species to TBT pollution, the only species that are more sensitive are other species of prosobranch molluscs. Protecting $95 \%$ of species in general would still exterminate the carnivorous neogastropods and also a number of deposit-feeders such as Scrobicularia plana, which can be considered as key species for ecosystem function. Therefore for specifically acting toxicants even stricter criteria should be argued for. In absence of other indicator species $L$. littorea can serve as a species for monitoring, however, when observed ISI levels in $L$. littorea do not exceed natural environmental background levels it is still likely that $10 \%$ of other species might be affected by TBT contamination.

Both calculated ISI and PAF values are based on the spatial distribution of concentrations. This distribution is derived from TBT concentrations in sediment and SPM. One complicating factor lies in the fact that, in most water systems, periwinkles do not live near the sampled sediment (which is also used to derive the water concentrations), but considerably higher up, on the hard substrates where the macro algae they feed on grow. There might therefore be no direct relationship between TBT in sediment in harbours and ISI values in periwinkles. Instead, the periwinkles are probably predominantly exposed to TBT dissolved in the water and adsorbed to SPM circulating in the water. The fair correspondence between observed and calculated ISI values for $L$. littorea as presented in this study shows that sediment and SPM concentrations, combined with a realistic partition coefficient $\left(\mathrm{K}_{\mathrm{oc}}\right)$, can be usefully applied to estimate effective concentrations in the water column.

With this relationship between predicted ISI in periwinkles and the PAF value, the ISI indicator might potentially not only serve as an indicator of TBT pollution but also to represent generic ecological health status. However, this relationship is useful only if many ISI measurements are available for an area, 
1 covering the whole distribution of possible ISI values. The wide range of ISI levels observed in Vlissingen harbour (location 25) indicates that a high variation in ISI levels can exist within a single harbour.

For open waters, only two measured ISI values fell within the predicted ISI ranges (North Sea (C)) and Western Scheldt (G), while the rest of the observations were below the calculated ranges. This is presumably a consequence of the asymptotic minimum of 0.07 in Formula 1 . Differences in local $\mathrm{K}_{\mathrm{oc}}$ values may have caused the predicted ISI levels in open waters to exceed the observed ISI values. In this study the $\mathrm{K}_{\mathrm{oc}}$ is based on measured concentrations in sediment and water from harbours. This is in line with the fact that the correspondence in harbours is much better. It might be possible to derive a dedicated $\mathrm{K}_{\mathrm{oc}}$ for open waters from the comparison of water and sediment concentrations in open waters, potentially improving the correspondence between predicted and measured ISI levels for these water systems. However, such data are not available. The possible over-estimation of water concentrations in open waters would also imply that the ecological risk values presented in this study have been overestimated for open waters.

There is good correspondence between observed ISI levels and the predicted ISI ranges for each harbour. Since almost all observed ISI levels fell within the ranges of predicted ISI levels in open waters, it can be concluded that the spatial distribution of TBT concentrations is a good basis for determining predicted ISI levels, and therefore ecological risk.

Periwinkles were found in low abundance at several harbour locations: Delfzijl (location 1); Harlingen (location 8); Den Helder (location 14); IJmuiden (location 15); and Rijnmond (location 18). It is unclear from the observations alone whether this was caused by high levels of TBT or other stress factors (e.g. salinity, excessive sand transport, etc.). The WOE approach can help to indicate the likelihood of TBT causing this absence. High risk values (PAF> 20\%) and maximum ISI levels have been predicted for Harlingen (location 8), Den Helder (location 14) and Rijnmond (location 18), so it is not unlikely that high TBT pollution caused the absence of periwinkles from these harbours.

Based on the evaluation of TBT effects on intersex development in the periwinkle $L$. littorea, and considering ecological health status as a criterion for decision-making, With reference to Table 3, LOEs were derived for $L$. littorea, representing the species used in the OSPAR monitoring guideline. The relationships between LOEs obtained from comparison of observed effects in the field aid the 
1 environmental assessment process. Table 3 brings together the objectives of the ecological health

2 strategy for TBT substances and existing action by water managers.

3 As gastropods are the most sensitive species to TBT, few of these species are likely to be present in a

4 TBT-contaminated harbour environment. The consequences of the absence of this group for the

5 functioning of the system should be evaluated. Probabilistic risk assessment based on chemical data

6 might provide a generic ecosystem health indicator related to TBT exposure to improve our

7 understanding of the impact of organotin pollution. The results of such an assessment should be

8 validated in the field, in order to reveal the actual field status. Given the relationships presented,

9 observations with ISI as a specific indicator could serve to validate the generic assessment. Inspection of

10 location-specific conditions alongside generic risk prognosis improves the assessment of impacts related

11 to TBT exposure. This study provides evidence of the poor ecological health status of some Dutch

12 harbours as a result of TBT pollution and promotes the use of integrated approaches like the WOE to help practitioners improve ecological impact assessment.

\section{Conclusion}

In this study an integrated ecological risk assessment including three LOEs has been applied to assess the risk from TBT pollution in coastal and harbour environments. Only two measured ISI values for coastal environments fell within the predicted ISI ranges (North Sea and Western Scheldt), while the rest of the observations were below the calculated ranges. In harbours there is good correspondence between observed ISI levels and the predicted ISI ranges for each harbour. This study provides evidence of the poor health status of some Dutch harbours as a result of TBT pollution and promotes the use of integrated approaches like the WOE to help practitioners improve ecological impact assessment. 
1

2

3

4

5

6 7

8

\section{Acknowledgements}

We would like to acknowledge the valuable contribution of the laboratory personnel at the DirectorateGeneral of Public Works and Water Management's (RWS) National Institute for Coastal and Marine Management (RIKZ) for the TBT analyses. The authors wish to express their gratitude to Johan Jol (IMARES) for his invaluable support in conducting the fieldwork. Ivonne Rietjens and Tinka Murk (WUR) are thanked for their critical review of a first version of the manuscript.

\section{Appendix A. Supplementary data}

Supplementary data associated with this article can be found, in the online version, at.....

\section{References}

Aldenberg, T., Slob, W., 1993. Confidence limits for hazardous concentrations based on logistically distributed NOEC toxicity data. Ecotoxicology and Environmental Safety, 25, 48-63.

Aldenberg, T., Jaworska, J.S., Traas, T.P., 2002. Normal species sensitivity distributions and probabilistic ecological risk assessment. In Posthuma, L., Suter II, G.W., and Traas, T.P., Species Sensitivity Distributions in Ecotoxicology Boca Raton: CRC Press, USA.

Bauer, B., Fioroni, P., Ide, I., Liebe, S., Oehlmann, J., Stroben, E., Watermann, B., 1995. TBT effects on the female genital system of Littorina littorea: A possible indicator of tributyltin pollution. Hydrobiologia, 309, 15-27.

Champ, P.M., Seligman, P.F., 1996. Organotin: Environmental Fate and Effects, Chapman \& Hall, London.

Chapman, P.M., 1996. Presentation and interpretation of Sediment Quality Triad data. Ecotoxicology, 5, 327-339.

De Wolf, H., de Coen, W., Backeljau, T., Blust, R., 2001. Intersex and sterility in the periwinkle Littorina littorea (Molluscs: Gastropoda) along the Western Scheldt estuary, the Netherlands. Marine Environmental Research, 52, 249-255. 


\section{ACCEPTED MANUSCRIPT}

1 De Wolf, H., Handa, C., Backeljau, T., Blust, R., 2004. A baseline survey of intersex in Littorina littorea along the Scheldt estuary, the Netherlands. Marine Pollution Bulletin, 48, 592-596.

EC, 2003. Technical Guidance Document on Risk Assessment in Support of Commission Directive 93/67/EEC on Risk Assessment for new notified substances, Commission Regulation (EC) No. 1488/94 on Risk Assessment for existing substances, and Directive 98/8/EC of the European Parliament and of the Council concerning the placing of biocidal products on the market. European Commission Joint Research Centre, EUR 20418 EN/2.

Harding, M.J.C., Bailey, S.K., Davies, I.M., 1992. TBT imposex survey of the North Sea. Series: Scottish Fisheries Working Paper No. 9/92, UK Department of the Environment, Aberdeen.

Lepper, P., 2002. Towards the derivation of quality standards for priority substances in the context of the Water Framework Directive. Final report of the study contract No. B4-3040/2000/30637/MAR/E1: Identification of quality standards for priority substances in the field of water policy. Fraunhofer Institute, Germany.

Marquenie, J.M., Vethaak, A.D., 1989. Effecten van verontreinigingen in zoutwater ecosystemen (Effects of pollutants in marine ecosystems). In Stortelder, P.M.B, and Kooper, W.F., Effecten van verontreinigde waterbodems op aquatische ecosystemen. (pp. 91-103). Vught: Vereniging voor Milieuwetenschappen, The Netherlands. (in Dutch with English summary).

Mensink, B.P., ten Hallers-Tjabbes, C.C., Kralt, J., Freriks, I.L., Boon, J.B., 1996. Assessment of imposex in the common whelk, Buccinum undatum (L.) from the Eastern Scheldt, the Netherlands. Marine Environmental Research, 41, 315-325.

Newman, M.C., Ownby, D.R., Mezin, L.C.A., Powell, D.C., Christensen, T.R.L., Lerberg, S.B., Anderson, B.A., 2000. Applying species-sensitivity distributions in ecological risk assessment: Assumptions of distribution type and sufficient numbers of species. Environmental Toxicology and Chemistry, 19, 508515. 
1 Oehlmann, J., Bauer, B., Minchin, D., Schulte-Oehlmann, U., Fioroni, P., Markert, B., 1998. Imposex in

2 Nucella lapillus and intersex in Littorina littorea: Interspecific comparison of two TBT-induced effects and

3 their geographical uniformity. Hydrobiologia, 378, 199-213.

4 Oehlmann, J., 2002. Baseline study on intersex in Littorina littorea with recommendations for biological

5 TBT assessment criteria. Report, Johann Wolfgang Goethe University, Frankfurt am Main. SIME 02/6/1-

$6 \quad$ E.

8 OSPAR, 2003. Harmonisation of Criteria for the Assessment of TBT-specific Biological Effects,

9 presented by the Netherlands, Meeting of the working group of monitoring (MON), 16 - 18 December

102003 in Copenhagen, document MON 03/3/1-E.

11 Posthuma, L., Traas, T.P., Suter II, G.W., 2002.. General introduction to Species Sensitivity Distributions.

12 In Posthuma, L., Suter II, G.W., and Traas, T.P., Species Sensitivity Distributions in Ecotoxicology

13 (pp.119-132). Boca Raton: CRC Press.

14 Rutgers, M., 2000. Site-specific ecological risks: a basic approach to the function-specific assessment of 15s soil pollution, ISBN: 9073270448, Wageningen, The Netherlands.

16 Schipper C.A.,Schout P., 2004. Towards implementation of a chemistry-toxicity testing tool. . National 17 Institute for Coastal and Marine Management (RIKZ), The Hague, The Netherlands, Report No RIKZ 182003.036.

19 Smit, M.G.D., Van Dalfsen, J.A., Karman, C.C., 2005. Linking the different worlds of environmental risk assessment and environmental effect monitoring. In Armsworthy, S.L., Cranford, P.J., and Lee, K.,

21 Offshore Oil and Gas Environmental Effects Monitoring: Approaches and Technologies. Battelle Press.

Smith E.P., Lipkovich, I., Ye. K., 2002. Weight of Evidence (WOE): Quantitative Estimation of Probability of Impact. Human and Ecological Risk Assessment, 8, 1585-1596.

Stroben, E., Oehlmann, J., Fioroni, P., 1992. Hinia reticulata and Nucella lapillus. Comparison of two gastropod tributyltin bioindicators. Journal of Marine Biology, 114, 289-296.

Suter II, G.W., 2001. Applicability of indicator monitoring to ecological risk assessment. Ecological Indicators, 1, 101-112. the open North Sea: Relation to shipping traffic intensities. Marine Pollution Bulletin, 28, 311-313. 


\section{ACCEPTED MANUSCRIPT}

1 Van der Hoeven, N., 2001. Estimating the 5-percentile of the species sensitivity distributions without any

2 assumptions about the distribution. Ecotoxicology, 10, 25-34.

3 Van Moorsel, G.W.N.M., 1996. Ecological profile of Nucella lapillus. National Institute for Coastal and

4 Marine Management (RIKZ), The Hague, The Netherlands, Report No RIKZ 96.01.

5 Van Straalen, N.M., Denneman, C.A.J., 1989. Ecotoxicological evaluation of soil quality criteria.

6 Ecotoxicology and Envionmental Safety, 18, 241-251. 


\section{ACCEPTED MANUSCRIPT}

1 Figure $1 \quad$ Map showing sampled harbours (1-30) and open waters (A-G) along the Dutch coast.

2 1. Delfzijl; 2. Emshaven, 3. Lauwersoog; 4. Schiermonnikoog; 5. Holwerd; 6. Ameland; 7. Terschelling;

3 8. Harlingen; 9. Kornwederzand; 10. Breezand; 11. Den Oever;

4 12. Vlieland; 13. Texel; 14. Den Helder; 15. IJmuiden; 16. Noordzeekanaal;

5 17. Scheveningen; 18. Rijnmond; 19. Herkingen; 20. Bruinisse; 21. Zierikzee;

6 22. Yerseke; 23. Colijnsplaat; 24. Hansweert; 25. Vlissingen; 26. Walsoorden;

7 27. Perkpolder; 28. Terneuzen; 29. Breskens; 30. Appelzak; A. Ems-Dollard;

$8 \quad$ B. Wadden Sea; C. North Sea; D. Grevelingen; E. Eastern Scheldt; F. Veersemeer;

$9 \quad$ G. Western Scheldt.

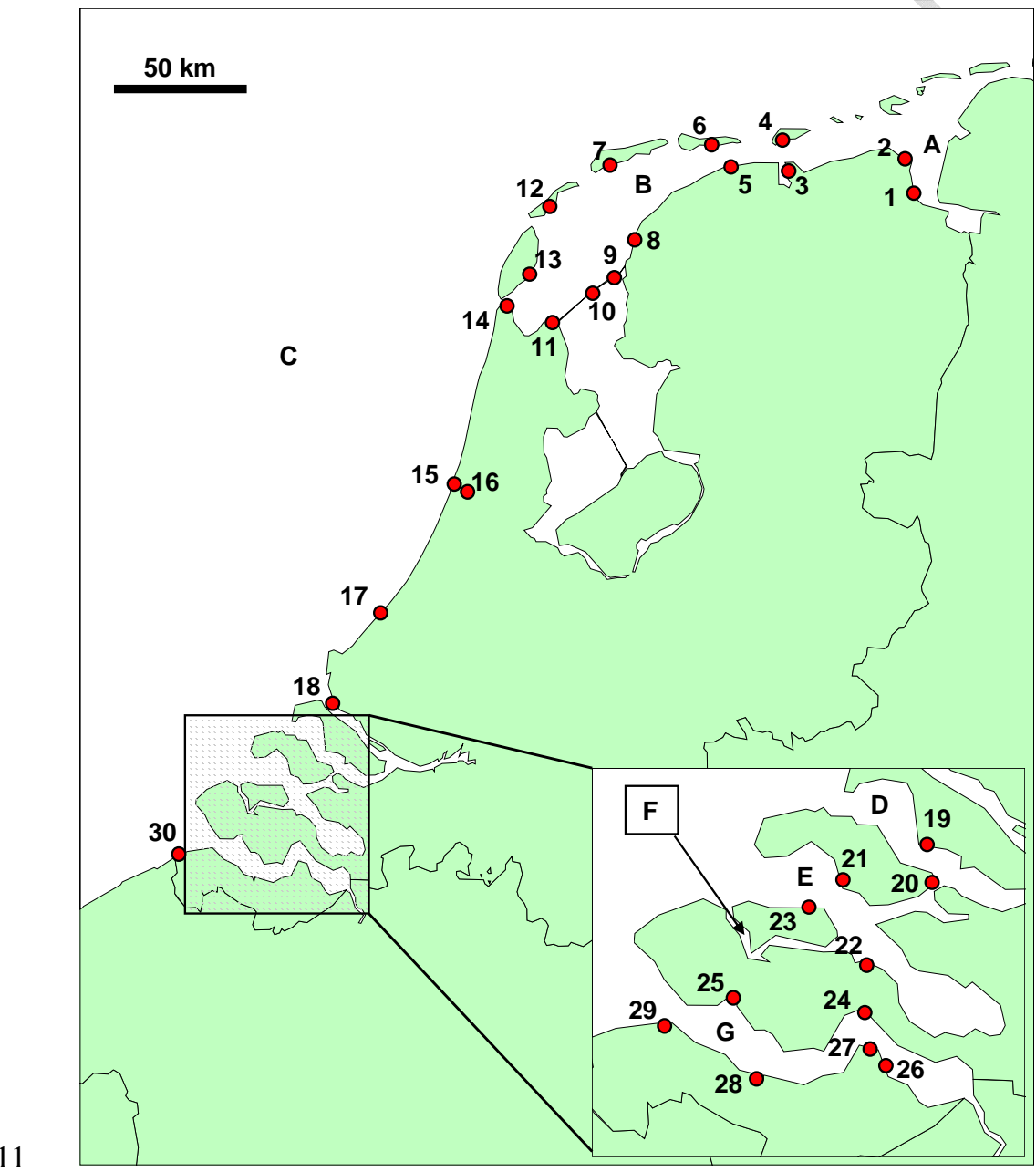



and harbours.

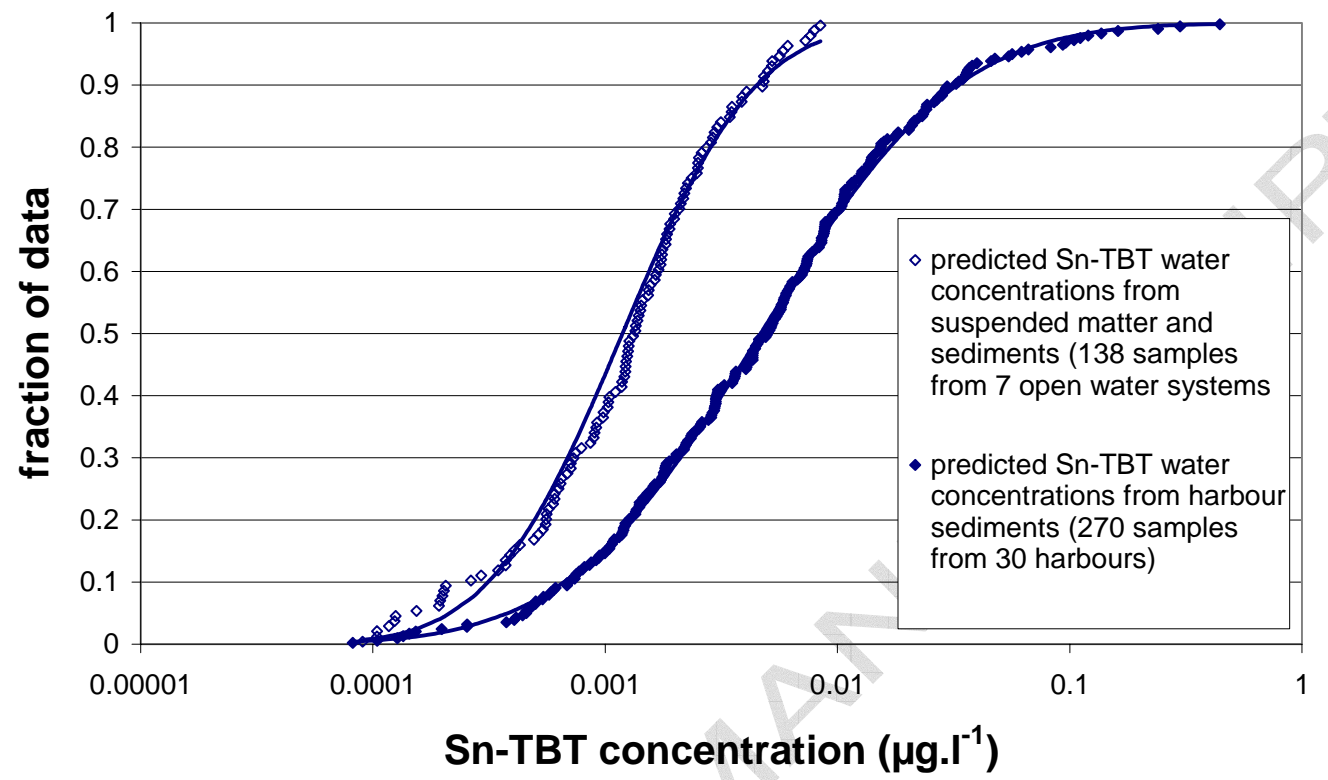


1

2 Figure 3 Correspondence between ecological risk expressed as the Potentially Affected Fraction

3 of species (PAF) and the calculated ISI level corresponding to the $95^{\text {th }}$ percentile exposure concentration

4 in Dutch harbours.

5

6

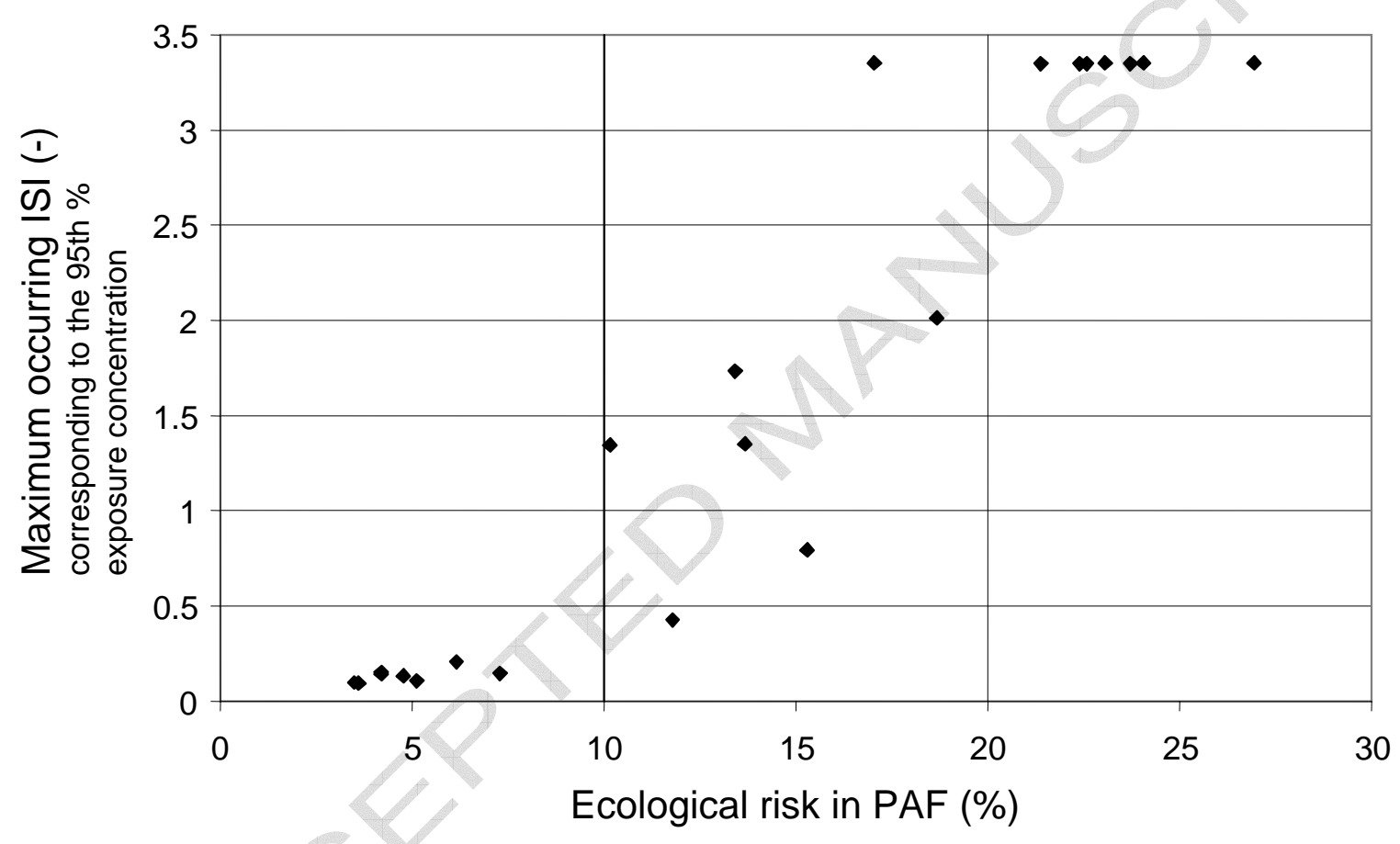




\section{ACCEPTED MANUSCRIPT}

1 Figure 4. Comparison of the observed ISI values and the predicted ISI ranges based on the

2 concentration distribution in the corresponding open waters (A) and harbours (B). The calculated ISI

3 values corresponding to the median and the 5th and 95th percentile of the exposure concentration

4 distribution are also shown. At some sampling locations in harbours periwinkles were rare, while at

5 other locations $(\dagger)$ no periwinkles were observed.

6

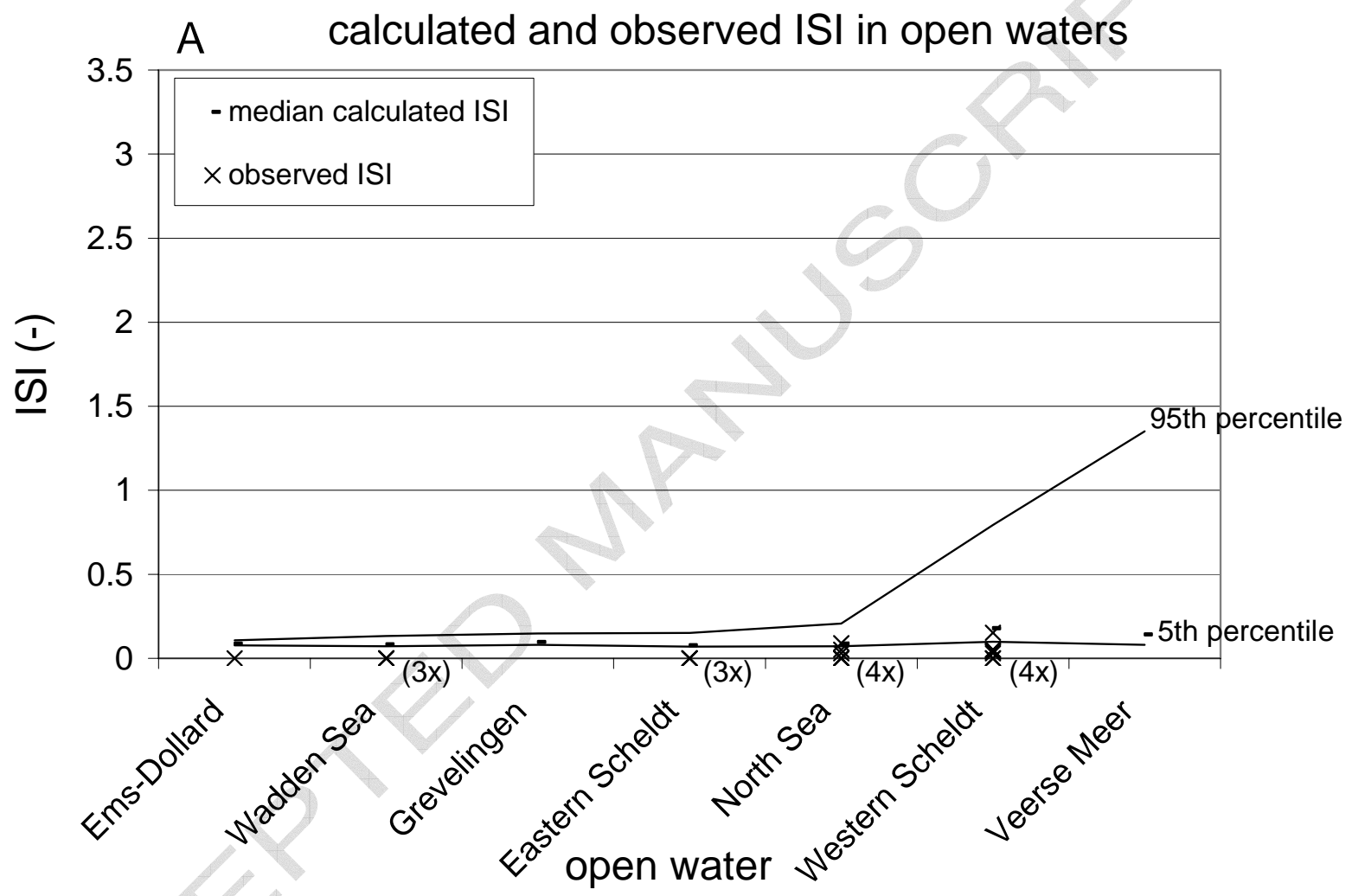




\section{ACCEPTED MANUSCRIPT}

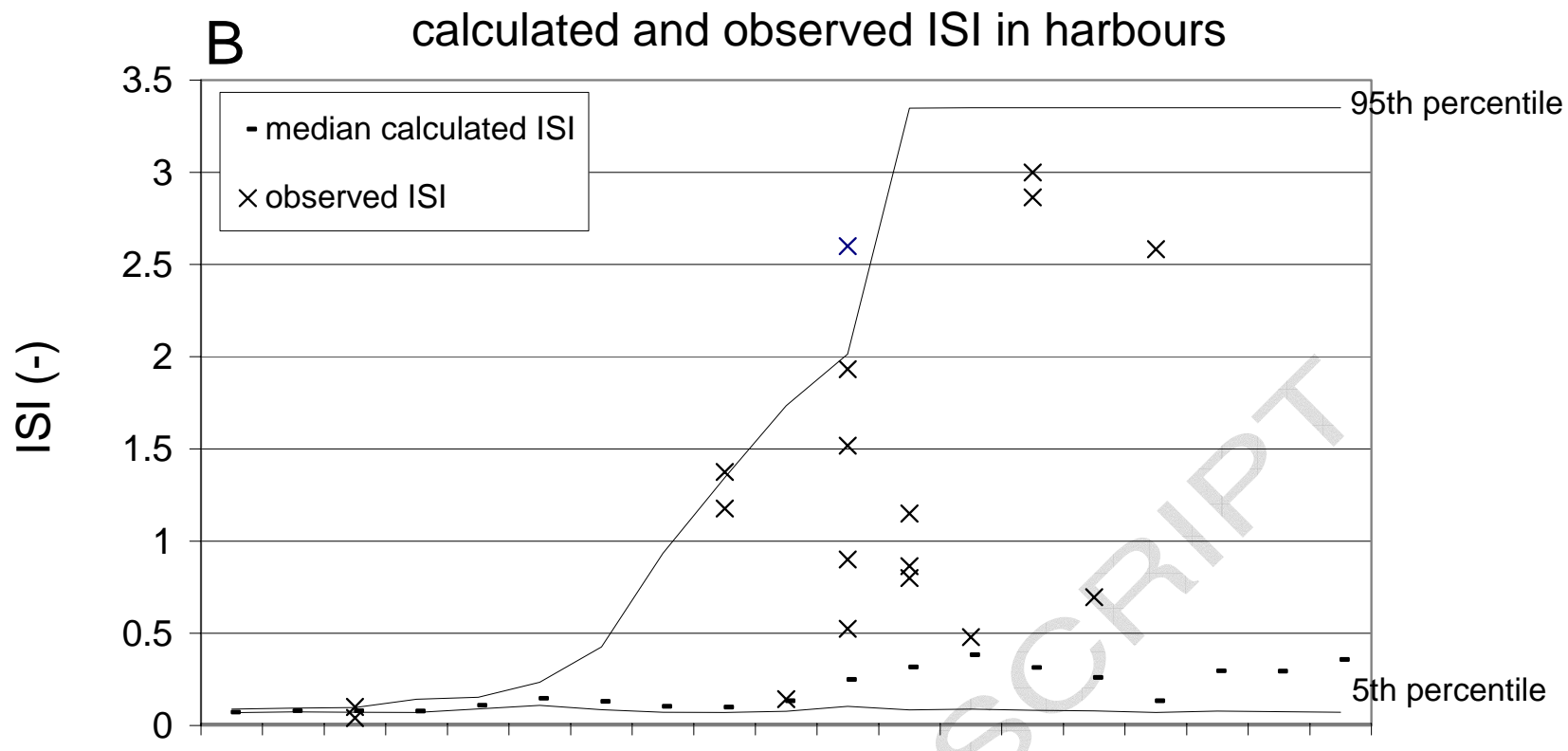

1

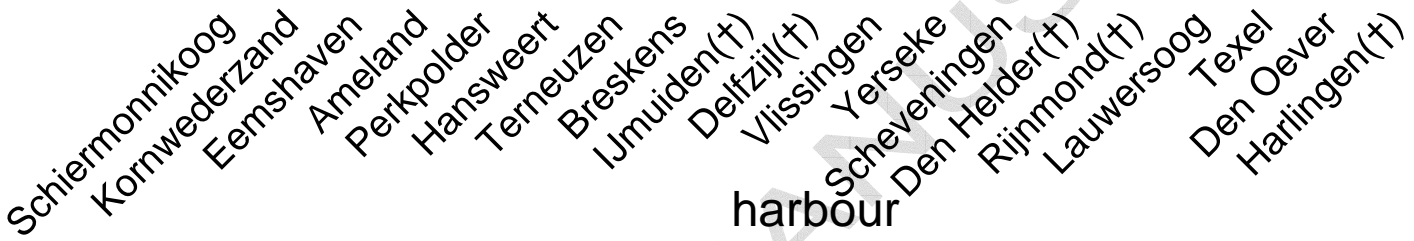

2

3 


\section{ACCEPTED MANUSCRIPT}

Table 1 Chemical and biological datasets used in this study

\begin{tabular}{|l|l|l|l|l|l|}
\hline Dataset & Area type & Medium & Time range & $\#$ areas & \# locations \\
\hline TBT concentrations & Open water & Suspended matter & $1998-2003$ & 5 & 25 \\
\hline TBT concentrations & Open water & Sediment & $1998-2003$ & 7 & 123 \\
\hline TBT concentrations & Harbour & Suspended matter & $1999-2002$ & 4 & 8 \\
\hline TBT concentrations & Harbour & Water & $1999-2002$ & 2 & 6 \\
\hline ISI values and abundance & Open water & Periwinkle & $2002-2005$ & 5 & 24 \\
\hline ISI values and abundance & Harbour & Periwinkle & $2002-2005$ & 9 & 18 \\
\hline
\end{tabular}

2

3

4

5

6

7

8

9

10

Table 2 Observed and predicted concentrations, ecological risk values and observed and predicted ISI

11

levels in different Dutch open waters. 


\section{ACCEPTED MANUSCRIPT}

\begin{tabular}{|c|c|c|c|c|c|c|}
\hline Area & \# locations & $\begin{array}{l}\text { Observed } \\
\text { concentration } \\
\text { range in } \\
\text { sediments and } \\
\text { SPM } \\
\text { Sn-TBT } \mu g . k^{-1}{ }^{-1} \\
\text { dw } \\
(\text { min - max })\end{array}$ & $\begin{array}{l}\text { Calculated } \\
\text { concentration } \\
\text { range in water } \\
\text { Sn-TBT ng.l }{ }^{-1} \\
(5 \text { - } 95 \% \text { tile })\end{array}$ & $\begin{array}{l}\text { Calcul } \\
\text { ated } \\
\text { Ecolo } \\
\text { gical } \\
\text { Risk } \\
\text { as } \\
\text { PAF } \\
(\%)\end{array}$ & $\begin{array}{l}\text { Calculated } \\
\text { predicted ISI range } \\
\text { (based on } \\
5 \text { - } 95 \% \text { tile } \\
\text { concentrations) }\end{array}$ & $\begin{array}{l}\text { Observed ISI } \\
(\min -\max )^{*}\end{array}$ \\
\hline \multicolumn{7}{|c|}{ Open waters } \\
\hline Ems-Dollard & 10 & $5.1-23.0$ & $0.59-2.20$ & 5.13 & $0.08-0.11$ & 0.00 \\
\hline Grevelingen Lake & 5 & $7.0-42.7$ & $0.79-3.72$ & 7.29 & $0.08-0.15$ & n.d. \\
\hline North Sea & 49 & $0.2-52.5$ & $0.23-5.45$ & 6.16 & $0.07-0.21$ & $0.00-0.09$ \\
\hline Eastern Scheldt & 15 & $0.2-24.4$ & $0.10-3.87$ & 4.2 & $0.07-0.15$ & $0.00(3 x)$ \\
\hline Veersemeer & 6 & $0.2-97.9$ & $0.76-16.4$ & 13.7 & $0.08-1.35$ & n.d. \\
\hline Western Scheldt & 13 & $7.4-160.7$ & $1.73-12.8$ & 15.3 & $0.10-0.80$ & $0.00-0.15$ \\
\hline Wadden Sea & 40 & $0.2-36.6$ & $0.25-3.23$ & 4.78 & $0.07-0.13$ & $0.00(3 x)$ \\
\hline All open waters & 138 & 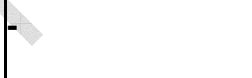 & - & 6.72 & & - \\
\hline \multicolumn{7}{|c|}{ Harbours } \\
\hline Schiermonnikoog & 2 & $0.5-0.5$ & $0.04-1.22$ & 1.56 & $0.07-0.09$ & n.d. \\
\hline Emshaven & 5 & $1.8-12$ & $0.29-1.71$ & 3.50 & $0.07-0.10$ & $0.04-0.10$ \\
\hline Kornwederzand & 3 & $4.8-15$ & $0.37-1.55$ & 3.61 & $0.07-0.09$ & n.d. \\
\hline Ameland & 4 & $0.5-25$ & $0.12-3.60$ & 4.21 & $0.07-0.14$ & n.d. \\
\hline Perkpolder & 2 & $3.9-24$ & $1.36-3.92$ & 8.92 & $0.09-0.15$ & n.d. \\
\hline IJmuiden $^{\dagger}$ & 32 & $0.5-980$ & $0.20-16.4$ & 10.2 & $0.07-1.35$ & $1.18-1.38$ \\
\hline Breskens & 2 & $0.5-13$ & $0.29-13.8$ & 10.2 & $0.07-0.93$ & n.d. \\
\hline
\end{tabular}




\section{ACCEPTED MANUSCRIPT}

\begin{tabular}{|c|c|c|c|c|c|c|}
\hline Terneuzen & 6 & $4.3-24$ & $1.06-9.19$ & 11.8 & $0.09-0.43$ & n.d. \\
\hline Hansweert & 2 & $19-37$ & $2.27-6.07$ & 12.6 & $0.11-0.23$ & n.d. \\
\hline Delfzijl $^{\dagger}$ & 11 & $6.8-240$ & $0.57-18.6$ & 13.4 & $0.08-1.73$ & 0.14 \\
\hline Lauwersoog & 6 & $0.5-210$ & $0.15-70.3$ & 17.0 & $0.07-3.35$ & 2.58 \\
\hline Vlissingen & 7 & $3.4-180$ & $2.01-20.2$ & 18.7 & $0.10-2.01$ & $0.52-2.60$ \\
\hline Rijnmond $^{\dagger}$ & 124 & $0.5-5700$ & $0.70-61.9$ & 21.4 & $0.08-3.35$ & 0.70 \\
\hline Yerseke & 3 & $16-250$ & $1.04-56.1$ & 22.4 & $0.08-3.35$ & $0.80-1.15$ \\
\hline Den Helder $^{\dagger}$ & 12 & $3.2-460$ & $0.93-61.6$ & 22.6 & $0.08-3.35$ & $2.86-3.00$ \\
\hline Texel & 7 & $4.1-190$ & $0.61-86.8$ & 23.1 & $0.08-3.35$ & n.d. \\
\hline Scheveningen & 8 & $7-370$ & $1.21-61.3$ & 23.7 & $0.09-3.35$ & 0.48 \\
\hline Den Oever & 5 & $4.2-110$ & $0.41-127.0$ & 24.0 & $0.07-3.35$ & n.d. \\
\hline Harlingen $^{\dagger}$ & 15 & $0.5-1700$ & $0.27-255.4$ & 26.9 & $0.07-3.35$ & - \\
\hline All harbours & 270 & - & 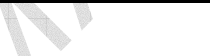 & 19.1 & - & - \\
\hline
\end{tabular}

1 * Where no range was measured, single values are reported in the table.

$2 \quad{ }^{\dagger}$ No periwinkles were present at any sampling stations.

3 n.d. = location not sampled

4

5

6 


\section{ACCEPTED MANUSCRIPT}

1 Table 3 Combinations of LOE results and likely ecological health status in relation to TBT pollution.

\begin{tabular}{|c|c|c|c|c|}
\hline $\begin{array}{l}\text { LOE - } \\
\text { Chemistry } \\
\text { Predicted } \\
\text { risk; } \\
\text { Predicted ISI }\end{array}$ & $\begin{array}{l}\text { LOE - } \\
\text { Toxicology } \\
\text { Observed ISI }\end{array}$ & $\begin{array}{l}\text { LOE - } \\
\text { Ecology } \\
\text { Presence of } \\
\text { gastropods at } \\
\text { all locations }\end{array}$ & $\begin{array}{l}\text { Likely } \\
\text { ecological } \\
\text { health status in } \\
\text { relation to TBT }\end{array}$ & Action \\
\hline $\begin{array}{l}\mathrm{PAF}<10 \% \\
\text { ISI }<0.3\end{array}$ & ISI $<0.3$ & + & Good & No action \\
\hline $\begin{array}{l}\text { PAF }<10 \% ; \\
\text { ISI }<0.3\end{array}$ & ISI $<0.3$ & - & Good & $\begin{array}{l}\text { Other stressors } \\
\text { present? }\end{array}$ \\
\hline $\begin{array}{l}\text { PAF > 10\%; } \\
\text { ISI }>0.3\end{array}$ & ISI $<0.3$ & + or - & Probably poor & $\begin{array}{l}\text { Extend } \\
\text { monitoring }\end{array}$ \\
\hline $\begin{array}{l}\text { PAF > 10\%; } \\
\text { ISI }>0.3\end{array}$ & ISI $>0.3$ & + & Poor & $\begin{array}{l}\text { Mitigating } \\
\text { measures and } \\
\text { monitoring of } \\
\text { recovery }\end{array}$ \\
\hline $\begin{array}{l}\text { PAF }>10 \% ; \\
\text { ISI }>0.3\end{array}$ & & - & Poor & $\begin{array}{l}\text { Mitigating } \\
\text { measures and } \\
\text { monitoring of } \\
\text { recovery }\end{array}$ \\
\hline
\end{tabular}

2 LOE $=$ Integrated ecological risk assessment is based on multiple Lines Of Evidence

3

4 